\title{
THE APPLICATION OF U-SHAPE HEAT PIPE HEAT EXCHANGER TO REDUCE RELATIVE HUMIDITY FOR ENERGY CONSERVATION IN HEATING, VENTILATION, AND AIR CONDITIONING (HVAC) SYSTEMS
}

\author{
Aliefka Satria Kusumah ${ }^{1}$, Imansyah Ibnu Hakim ${ }^{1}$, Ragil Sukarno ${ }^{1}$, Fadhil Fuad Rachman ${ }^{1}$, \\ Nandy Putra ${ }^{*}$ \\ ${ }^{1}$ Applied Heat Transfer Research Group, Department of Mechanical Engineering, \\ Faculty of Engineering, Universitas Indonesia, Kampus UI Depok, Depok 16424, Indonesia
}

(Received: August 2019 / Revised: October 2019 / Accepted: October 2019)

\begin{abstract}
Hospitals consume large amounts of energy, especially in their heating, ventilation, and air conditioning (HVAC) systems due to the special requirements for ensuring healthy, comfortable, and safe environmental conditions. The use of a Heat Pipe Heat Exchanger (HPHE) is recommended as a means of minimizing electricity consumption with no loss of comfort while also improving indoor air quality. An experimental study was conducted to investigate the performance of a U-shape HPHE in recovering exhaust air heat from an indoor room included in an HVAC system. The U-shape HPHE consists of several tubular U-shape heat pipes with water as a working fluid and arranged in a staggered configuration. Tests were carried out to determine the impact of the inlet air temperature, air velocity, and the number of heat pipes on its effectiveness. The experiment revealed that the higher the temperature of the inlet air, the more effective the U-shape HPHE. The results show that the temperature of the air entering the cooling coil decreased by $1.73{ }^{\circ} \mathrm{C}$ with an effectiveness value of $7.64 \%$. This result was achieved using 12 U-shape HPHEs, which had a staggered arrangement, an air velocity of $1.5 \mathrm{~m} / \mathrm{s}$, and an air temperature entering the evaporator of $45{ }^{\circ} \mathrm{C}$. The highest amount of heat recovery, 2190.43 $\mathrm{kJ} /$ hour, was achieved when the air velocity was $2.5 \mathrm{~m} / \mathrm{s}$.
\end{abstract}

Keywords: Effectiveness; Heat Recovery; HVAC; U-shape Heat Pipe

\section{INTRODUCTION}

Hospitals and health facilities are responsible for excessive energy demands. Increasing energy demand, in the context of limited availability of fossil energy resources, is encouraging people to find alternative energy sources (Elfani, 2011) and more efficient ways in which to use energy (Vakiloroaya et al., 2014). Research from the Energy Star program shows that energy consumption per $\mathrm{m}^{2}$ in hospitals greatly exceeds that found in many other types of buildings (World Health Organization, 2014). The air quality in every hospital operating room must be kept sterile; thus, special places such as operating rooms in hospitals usually require air temperatures in the range of $20{ }^{\circ} \mathrm{C}-24{ }^{\circ} \mathrm{C}$, relative humidity between $50 \%$ and $60 \%$, and for positive air pressure to be maintained (Leung \& Chan, 2006). As the ASHRAE Standard states, "Relative humidity in inhabitable spaces should be maintained between $30 \%$ and $60 \%$, to minimize the growth of allergenic or pathogenic organisms" (ASHRAE Standard, 1981). The use of a conventional cooling coil to obtain relative air humidity following the standard demands a process for reheating air from the dew point prior to its distribution to the conditioned room, which

${ }^{*}$ Corresponding author's email: nandyputra@eng.ui.ac.id, Tel. +62-21-7270032, Fax.+62-21-7270033

Permalink/DOI: https://doi.org/10.14716/ijtech.v10i6.3650 
requires an external energy source (Bearg, 1992).

The Heat Pipe Heat Exchanger (HPHE) may offer a solution to this problem. Warm air from outside is recovered by the HPHE to reheat the cold air at the dew point, thereby saving reheating energy. The evaporator section of a U-shape HPHE can serve as a precooler of warm air before it is cooled by a cooling coil device, thus increasing the capability of the cooling coil.

McFarland et al. (1996) and Abtahi et al. (1988) conducted experiments to determine the effect of using an HPHE on the performance of conventional air conditioning systems. In their experiments, three configurations of the system were applied: a system with HPHE installed, a system without HPHE, and the use of a damper system. The results showed that the utilization of HPHE in conventional air conditioning systems has a significant effect in terms of controlling humidity and reducing energy consumption (Abtahi et al., 1988) (McFarland et al., 1996). An experimental study on the use of an HPHE to cool the fresh air inlet in a heating, ventilation, and air conditioning (HVAC) system was also conducted by El-Baky and Mohamed (2007). Their results revealed that effectiveness of up to $48 \%$ could be achieved when the temperature of the fresh air was $40{ }^{\circ} \mathrm{C}$. In addition, they found that heat recovery could be increased to $85 \%$ with a higher temperature of fresh air entering the inlet (El-Baky \& Mohamed, 2007).

The heat pipe is thus a beneficial device within energy recovery systems (Srimuang \& Amatachaya, 2012). Several types of heat pipes have been applied, such as straight heat pipes (Putra et al., 2017), thermosyphon (Jouhara \& Merchant, 2012), oscillating heat pipes (Winarta et al., 2019), and a wraparound loop heat pipe (Jouhara \& Meskimmon, 2018). An HVAC system with an HPHE installed provides the benefit of acting as heat recovery equipment, mainly when used in the operating room of a hospital (Shabgard et al., 2015). Therefore, this recent research aims to investigate the thermal performance and energy recovery associated with the use of a Ushape HPHE in an HVAC system.

\section{METHODS}

This paper focuses on the effect of U-shape heat pipes applied around a conventional cooling coil.

\subsection{Design and Specifications}

Heat pipes are devices that have a high effective conductivity that consists of closed tubes containing appropriate working fluids, such as water and ammonia, that allow very high heat transfer rates (Ting et al., 2009) (Firouzfar et al., 2011). Figure 1(a) illustrates the type of U-shape heat pipe used in this study. Figure 1(b) shows how the U-shape HPHE without fins is staggered. The evaporator section of the U-shape HPHE is placed before the cooling coil for precooling, and the condenser section is mounted after the cooling coil for reheating. The U-shape HPHE specifications used in this experiment are shown in Table 1.

Table 1 HPHE U-shape specifications

\begin{tabular}{ll}
\hline Outer diameter of tube & $10 \mathrm{~mm}$ \\
Length of tube & $720 \mathrm{~mm}$ \\
Number of tubes and their arrangement & $2,4,6$ (inline), and 12 heat pipes (staggered) \\
\hline
\end{tabular}




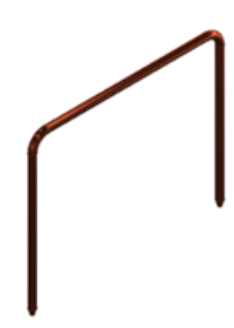

(a)

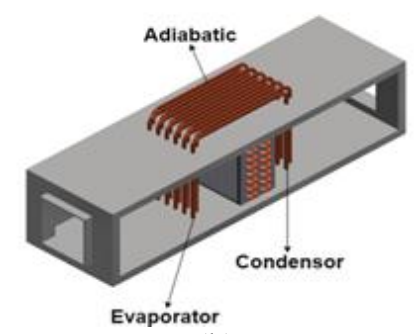

(b)

Figure 1 (a) U-shaped heat pipe used in this study; (b) The dimensions of the U-shape HPHE without fins are staggered

\subsection{Experimental Setup}

A schematic of the experiment performed in this analysis is shown in Figure 2. It contains other devices including the inlet and outlet fan, HPHE, cooling coil, condensers, and space simulator, as well as several pieces of measuring equipment attached to the tube. The design work started with the axial inlet ventilator that brings air into the HVAC system. The fan was used to blast fresh air into the tube at velocities of $1.5,2.0$, and $2.5 \mathrm{~m} / \mathrm{s}$, and the air velocity was measured using a Lutron AM-4204 water wire anemometer.

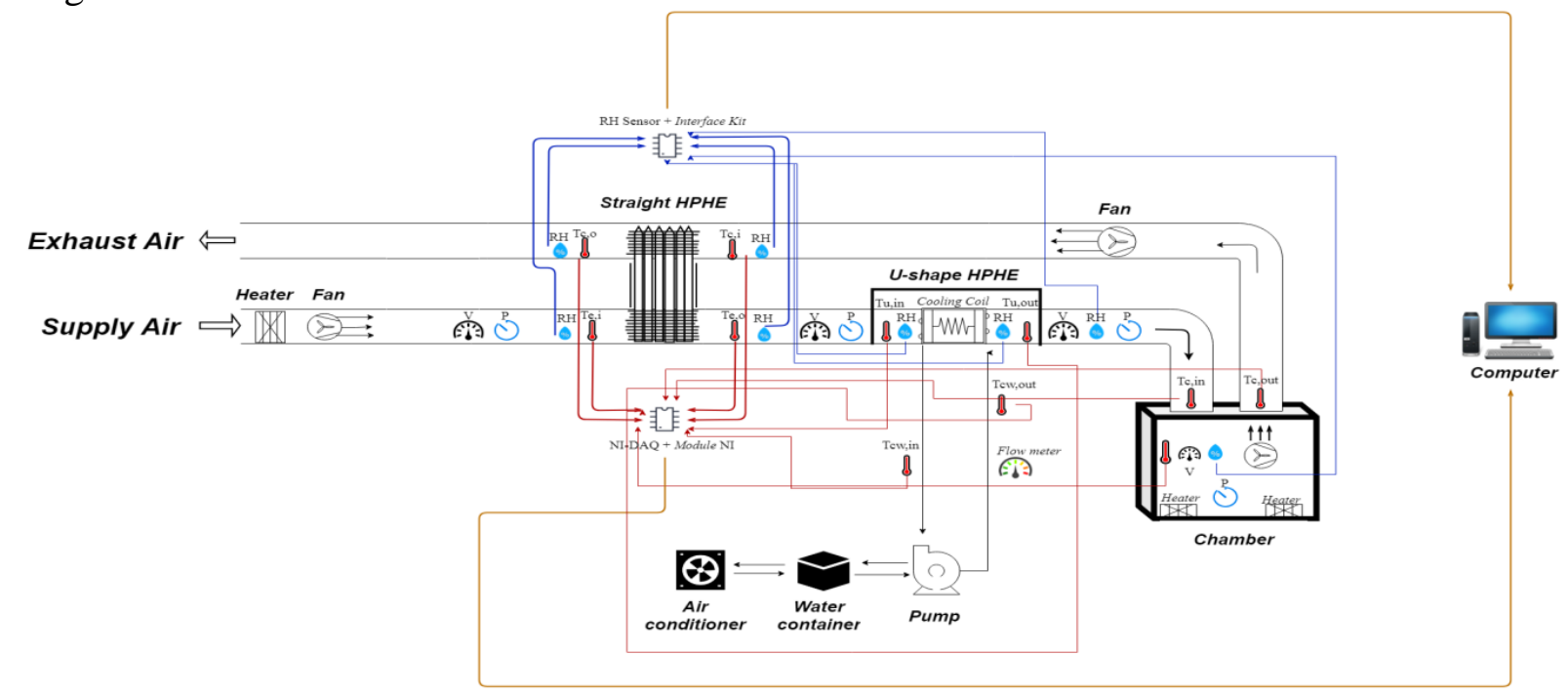

Figure 2 Experimental schematic

Upon making contact with the evaporator section of the HPHE, the water inlet must be cooled (pre-cooled). The cooling process was also carried out by cooling the coil to reduce the space simulator temperature. Waste air from the simulation room ran to the top of the pipe at a lower temperature than the drain temperature as it was used to cool the portion of the HPHE condenser. The U-shape HPHE numbers were 2, 4, 6, and 12, respectively. The independent variable, the air velocity, was set to $1.5,2.0$, or $2.5 \mathrm{~m} / \mathrm{s}$, depending on the pre-determined length. The heating component with the PID-controller controlled the temperature of the incoming air and maintained averages of $30,35,40$, and $45^{\circ} \mathrm{C}$ before the air flowed into the input panel. The temperature was measured using type- $\mathrm{K}$ thermocouples, with a total of eight thermocouples for the duct and ambient, seven thermocouples (before and after HPHE) for the air temperature measurement, and one thermocouple for ambient measurement. Seven relative humidity (before and after HPHE) sensors and one sensor were used to measure the ambient conditions as part of the measurement of relative humidity. The temperature sensors of the type-K thermocouples were connected to module NI 9214, and the relative humidity sensors from the Autonic THD series were connected 
to module NI 9207, which was connected to a data-acquisition device (NI cDAQ-9174). Next, the air flowed into the ducting with inlet dimensions of $210 \mathrm{~mm}$ x $160 \mathrm{~mm}$ and passed through a straight heat pipe, which amounted to three modules, prior to undergoing precooling. The outlet air velocity was set equal to the inlet air velocity. The return air from the simulator room that had a low temperature then passed through a straight heat pipe condenser for heat recovery. Figures 3 and 4 show the design and appearance of the ducting system used and its components.

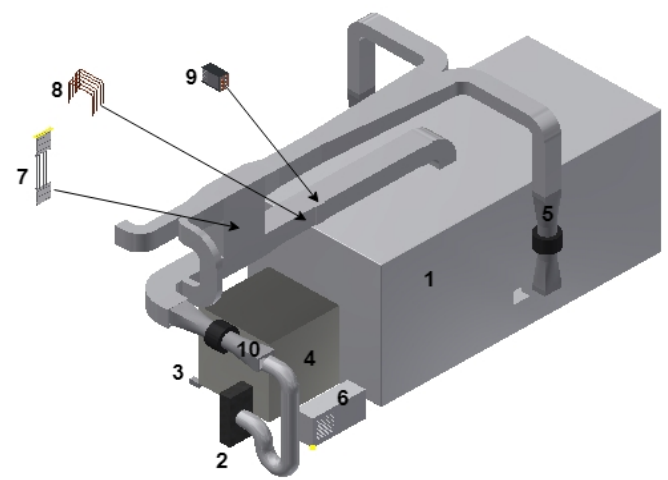

Figure 3 Ducting design and its components

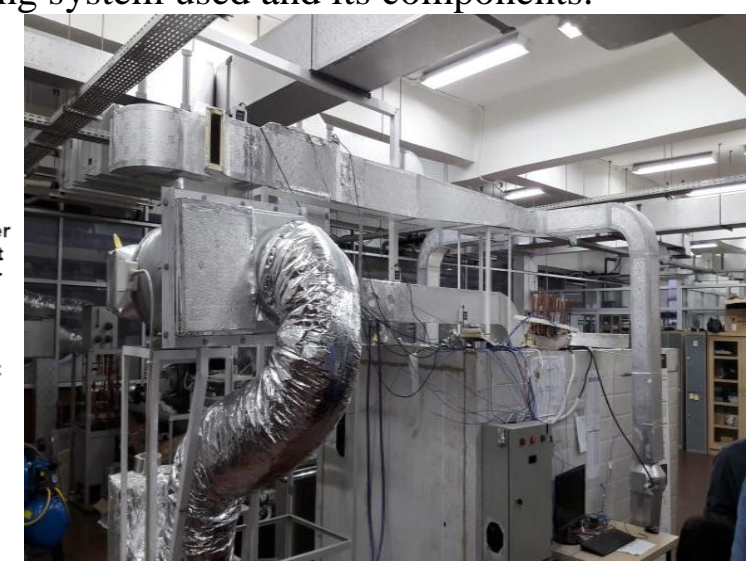

Figure 4 Equipment test simulator

\subsection{Effectiveness Calculation Procedure}

Thermal effectiveness calculated using Equation 1 was used to determine the performance of the U-shaped HPHE used in the HVAC system. Efficacy is defined as the actual to the highest heat transfer ratio in the HPHE (Jouhara, 2009; Hassan, 2012; Putra et al., 2017; Hakim et al., 2018; Jouhara \& Meskimmon, 2018; Muhammaddiyah et al., 2018).

$$
\varepsilon=\frac{Q_{a c t}}{Q_{\max }} ; \quad \varepsilon=\frac{T_{e, i n}-T_{e, o u t}}{T_{e, \text { in }}-T_{c, i n}}
$$

where $\varepsilon$ is the effectiveness of HPHE, $\mathrm{T}_{\mathrm{e}, \text { in }}$ is the temperature of the HPHE evaporator inlet $\left({ }^{\circ} \mathrm{C}\right), \mathrm{T}_{\mathrm{e}, \text { out }}$ is the temperature of the HPHE evaporator outlet $\left({ }^{\circ} \mathrm{C}\right), \mathrm{T}_{\mathrm{c}, \text { in }}$ is the temperature of the HPHE condenser inlet $\left({ }^{\circ} \mathrm{C}\right), \mathrm{T}_{\mathrm{e}, \text { out }}$ is the temperature of the HPHE condenser outlet $\left({ }^{\circ} \mathrm{C}\right)$.

Table 2 below shows the experiment matrix used in this study.

Table 2 Experiment matrix

\begin{tabular}{cccc}
\hline No. & $\begin{array}{c}\text { Air velocity of the evaporator inlet } \\
(\mathrm{m} / \mathrm{s})\end{array}$ & $\begin{array}{c}\text { Air evaporator inlet } \\
\text { temperature }\left({ }^{\circ} \mathrm{C}\right)\end{array}$ & $\begin{array}{c}\text { Number of U- } \\
\text { shaped HPHEs }\end{array}$ \\
\hline 1. & 1.5 & $30,35,40,45$ & $2,4,6,12$ \\
2. & 2.0 & $30,35,40,45$ & $2,4,6,12$ \\
3. & 2.5 & $30,35,40,45$ & $2,4,6,12$ \\
\hline
\end{tabular}

\section{RESULTS AND DISCUSSION}

\subsection{Temperature and Relative Humidity Profile}

Figure 5 shows the temperature profile, consisting of evaporator straight HPHE inlet, evaporator straight HPHE outlet (evaporator U-shape HPHE inlet), condenser straight HPHE inlet, condenser straight HPHE outlet, evaporator U-shape HPHE outlet, condenser U-shape HPHE inlet, and condenser U-shape HPHE outlet. The figure shows an experimental result with the parameters $\left(T_{e, i n}\right)=30,35,40,45^{\circ} \mathrm{C}, \mathrm{Ve}, \mathrm{i}=1.5 \mathrm{~m} / \mathrm{s}$ and uses $12 \mathrm{U}$-shape HPHEs, which are staggered. Figure 5 shows that the U-shape HPHE can reduce the air temperature that passes 
through the straight type of HPHE. There is a decrease of $0.57^{\circ} \mathrm{C}$ in the temperature of the air from the inlet of a U-shape HPHE $\left(T_{e}-U\right.$ in) to the outlet of a U-shape HPHE at an inlet temperature of $30^{\circ} \mathrm{C}$; a decrease of $1.00^{\circ} \mathrm{C}$ at an inlet temperature of $35^{\circ} \mathrm{C} ; 1.42^{\circ} \mathrm{C}$ at an inlet temperature of $40^{\circ} \mathrm{C}$; and $1.73^{\circ} \mathrm{C}$ at an inlet temperature of $45^{\circ} \mathrm{C}$. From this figure it can be seen that the U-shape HPHE has a precooling effects. After air flows through the condenser section of the U-shape HPHE, the temperature of the air increases. This is indicated by the value of TcU,out, which is higher than the value of TcU,in and is caused by the release of heat absorbed by the condenser. In this test, the increase in air temperature in the condenser section is $6.78{ }^{\circ} \mathrm{C}$ at the inlet temperature of $30^{\circ} \mathrm{C} ; 6.83^{\circ} \mathrm{C}$ at the inlet temperature of $35^{\circ} \mathrm{C} ; 6.97^{\circ} \mathrm{C}$ at the inlet temperature of $40^{\circ} \mathrm{C}$; and $7.08^{\circ} \mathrm{C}$ at the inlet temperature of $45^{\circ} \mathrm{C}$. From the increasing air temperature in the condenser section, it can be seen that the U-shape HPHE has a reheating function.

Figure 6 shows the relative humidity profile, which uses the same measurement intervals as the temperature profile shown in Figure 5. When passing through the U-shape HPHE evaporator section, the relative humidity of the air shows an increase of $2.28 \%$ from the evaporator inlet, $\mathrm{RHe}-\mathrm{U}$, to the evaporator outlet, $\mathrm{RHe}-\mathrm{U}$,out at an inlet temperature of $30^{\circ} \mathrm{C} ; 3.5 \%$ at an inlet temperature of $35^{\circ} \mathrm{C} ; 3.59 \%$ at an inlet temperature of $40^{\circ} \mathrm{C}$; and $3.64 \%$ at an inlet temperature of $45^{\circ} \mathrm{C}$. A decrease in evaporator temperature causes a reduction in water vapor saturation pressure, thus causing the relative humidity of the air to rise. Meanwhile, after passing the U-shape condenser section, there was a decrease of $12.2 \%$ in the relative humidity from the condenser inlet, RHc-U,in to the evaporator outlet, RHc-U,out at the inlet temperature of $30^{\circ} \mathrm{C} ; 13.68 \%$ at the inlet temperature of $35^{\circ} \mathrm{C} ; 17.71 \%$ at the inlet temperature of $40^{\circ} \mathrm{C}$; and $19.3 \%$ at the inlet temperature of $45^{\circ} \mathrm{C}$. This decrease in relative humidity is due to the air receiving heat from the part of the condenser.

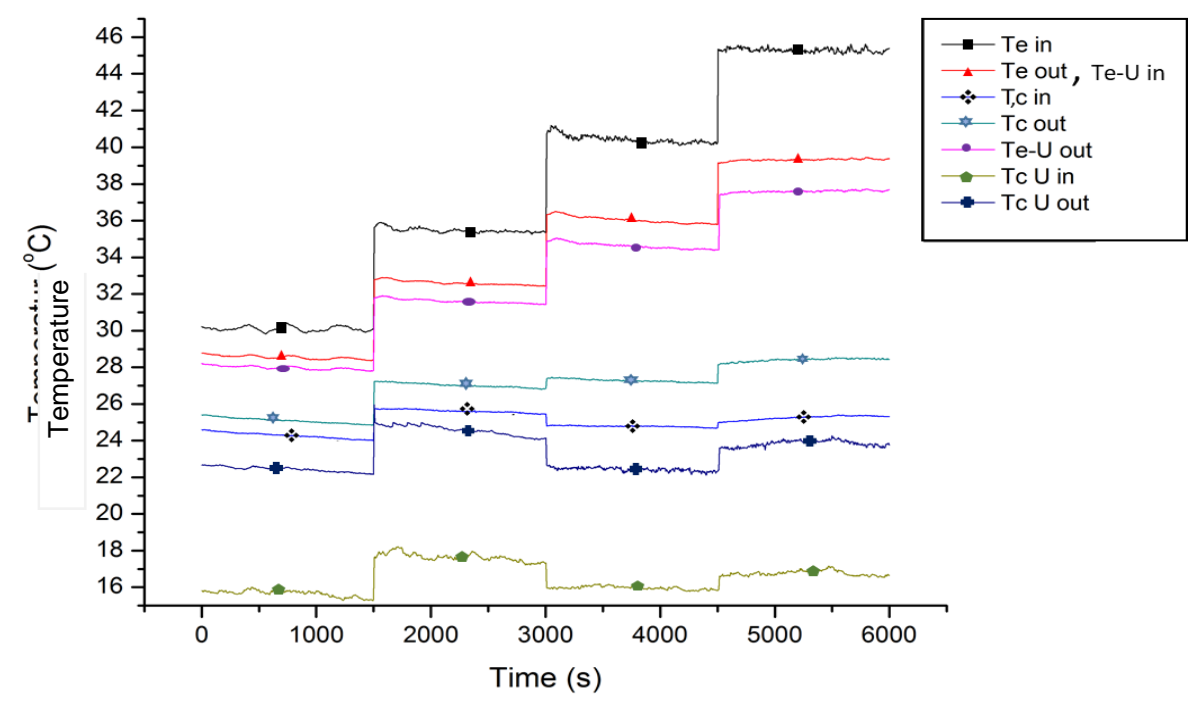

Figure 5 Temperature profile using 12 HPHEs and air inlet velocity of $1.5 \mathrm{~m} / \mathrm{s}$ 


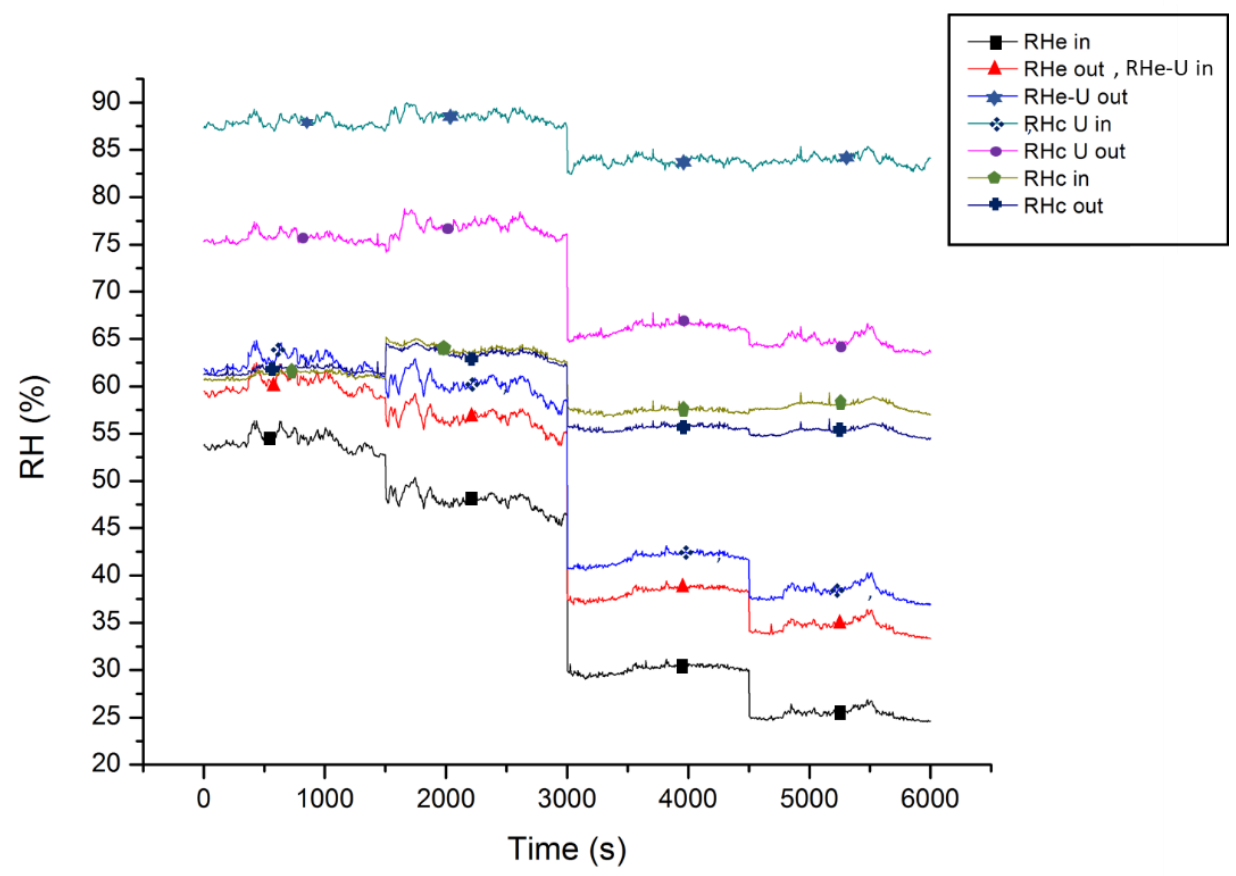

Figure 6 Profile of relative humidity using 12 HPHEs and air inlet velocity of $1.5 \mathrm{~m} / \mathrm{s}$

\subsection{The Performance of the Heat Pipe Heat Exchanger}

The greatest effectiveness value when testing the $12 \mathrm{U}$-shape HPHEs arranged in a staggered configuration was obtained at $\mathrm{Ve}, \mathrm{i}=1.5 \mathrm{~m} / \mathrm{s}$ and $\mathrm{Te}, \mathrm{i}=45^{\circ} \mathrm{C}$ and was equal to $7.64 \%$. The lowest effectiveness was obtained for the test with $\mathrm{Ve}, \mathrm{i}=2,0 \mathrm{~m} / \mathrm{s}$ and $\mathrm{Te}, \mathrm{i}=30^{\circ} \mathrm{C}$ and was equal to $4.43 \%$. Figure 7 shows that the effectiveness of the U-shape HPHE using 12 HPHEs is relative to the size of the evaporator intake air temperature $(\mathrm{Te}, \mathrm{i})$ and the air inlet velocity in the evaporator section (Ve, i). Figure 7 shows that the higher the Te,i value, the greater the effectiveness of the U-shape HPHE. The lower the value of Ve, i, the higher the effectiveness of the U-shape HPHE. Figure 8 also shows the effectiveness results when using 2 U-shape HPHEs, which are generally the same as in the previous test. The greatest effectiveness occurs at Te, $\mathrm{i}=$ $45^{\circ} \mathrm{C}$ and $\mathrm{Ve}, \mathrm{i}=1.5 \mathrm{~m} / \mathrm{s}$, which is equal to $5.72 \%$, while the lowest effectiveness value is at $\mathrm{Te}, \mathrm{i}=30^{\circ} \mathrm{C}$ and $\mathrm{Ve}, \mathrm{i}=2.5 \mathrm{~m} / \mathrm{s}$, which is equal to $0.30 \%$.

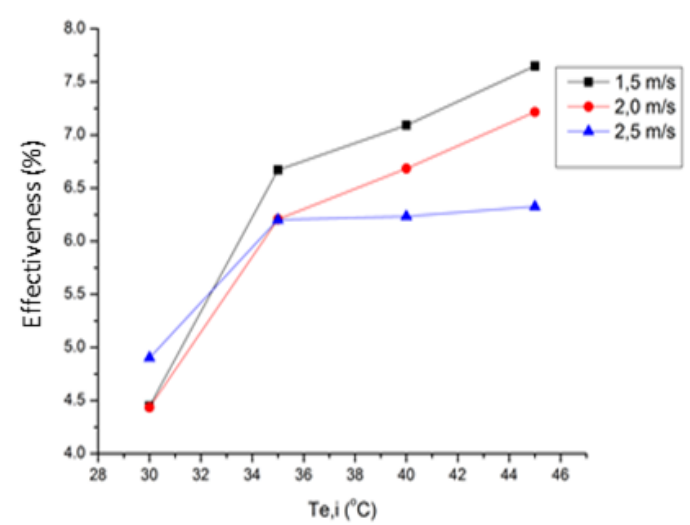

Figure 7 The effectiveness profile of HPHE with 12 U-shape HPHEs with respect to $\mathrm{Ve}, \mathrm{i}$ and $\mathrm{Te}, \mathrm{i}$

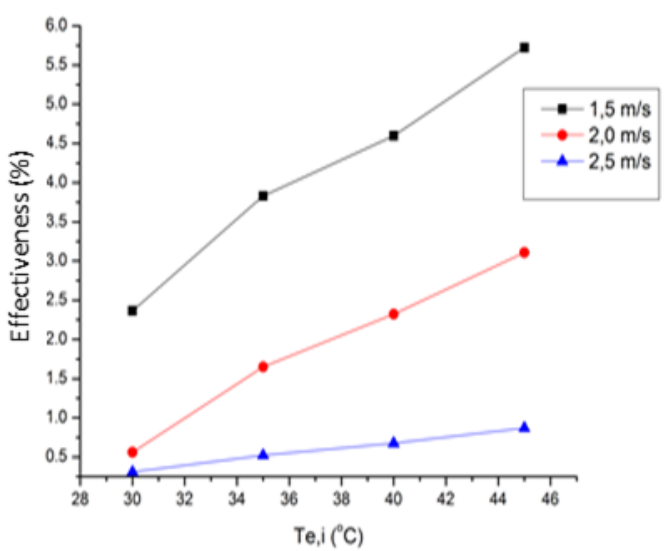

Figure 8 The effectiveness profile of HPHE with 2 U-shape PHHEs with respect to Ve, i and Te, i 


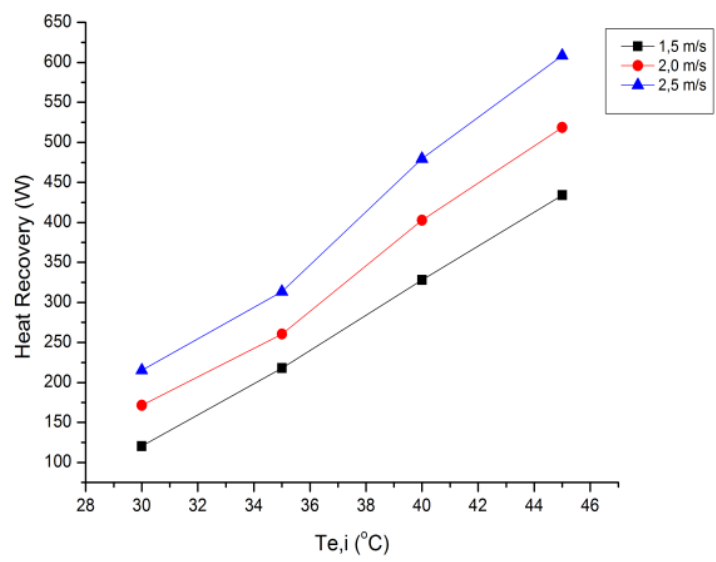

Figure 9 The profile of HPHE heat recovery using $12 \mathrm{U}$-shape HPHEs with respect to Ve, i and $\mathrm{Te}, \mathrm{i}$

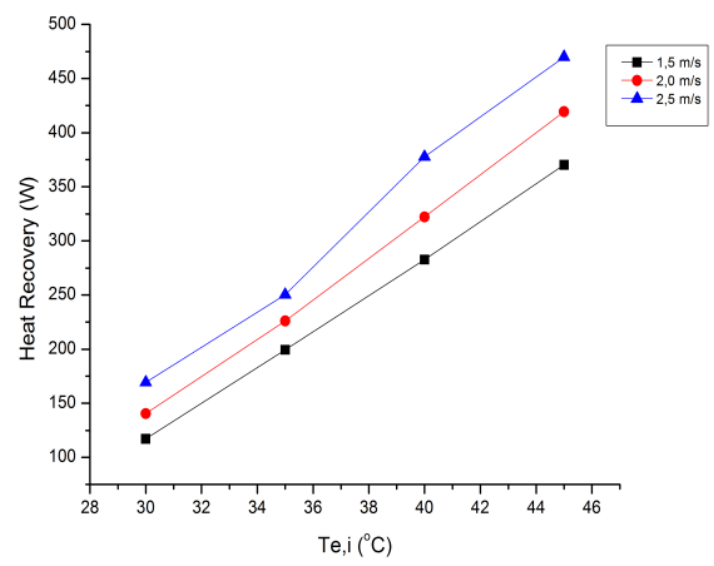

Figure 10 The profile of HPHE heat recovery using $12 \mathrm{U}$-shape HPHEs with respect to $\mathrm{Ve}$, i and $\mathrm{Te}, \mathrm{i}$

Figure 9 displays a graph of the heat recovery value of HPHE by testing using 12 U-shape HPHEs with respect to $\mathrm{Ve}, \mathrm{i}$ and $\mathrm{Te}, \mathrm{i}$. Here, the highest heat recovery value is obtained when the value of Te, $\mathrm{i}=45^{\circ} \mathrm{C}$ and $\mathrm{Ve}, \mathrm{i}=2.5 \mathrm{~m} / \mathrm{s}$, which is $608,45 \mathrm{~W}$.

The lowest value of heat recovery is obtained when the value of Te, $\mathrm{i}=30^{\circ} \mathrm{C}$ and $\mathrm{Ve}, \mathrm{i}=1.5 \mathrm{~m} /$ $\mathrm{s}$, which is equal to $120,48 \mathrm{~W}$ or $433,76 \mathrm{~J} / \mathrm{kg}$. K. Figure 10 also shows the HPHE heat recovery profile using $2 \mathrm{U}$-shape HPHEs. The highest heat recovery value is $470,03 \mathrm{~W}$ or $1692,12 \mathrm{~J} / \mathrm{kg}$. $\mathrm{K}$. The lowest heat recovery value is $117.21 \mathrm{~W}$ or $421.97 \mathrm{~J} / \mathrm{kg}$. K. The greatest HPHE effectiveness occurred in the testing of $12 \mathrm{U}$-shape HPHEs with Te, $\mathrm{i}=45^{\circ} \mathrm{C}$ and $\mathrm{Ve}, \mathrm{i}=1.5 \mathrm{~m} /$ $\mathrm{s}$, while the lowest HPHE effectiveness occurred in the $2 \mathrm{U}$-shape HPHEs test with Te, $\mathrm{i}=30^{\circ} \mathrm{C}$ and $\mathrm{Ve}, \mathrm{i}=2.5 \mathrm{~m} / \mathrm{s}$. The more U-shape HPHE configurations used, the greater the heat capacity that can be moved (Putra et al., 2017). In this test no fins were used in the HPHE configuration. Had fins been used, then this obviously would have increased the effectiveness of the HPHEs as fins have the effect of increasing the surface area that the air can pass over. The greatest amount of heat recovery occurred in the testing of $12 \mathrm{U}$-shape HPHEs with $\mathrm{Te}, \mathrm{i}=45^{\circ} \mathrm{C}$ and $\mathrm{Ve}, \mathrm{i}=2.5$ $\mathrm{m} / \mathrm{s}$, while the lowest effectiveness of the HPHEs occurred in the testing of $2 \mathrm{U}$-shape HPHEs with $\mathrm{Te}, \mathrm{i}=30^{\circ} \mathrm{C}$ and $\mathrm{Ve}, \mathrm{i}=1.5 \mathrm{~m} / \mathrm{s}$.

\section{CONCLUSION}

The chamber structures used in this analysis were modified to the standard conditions found in a hospital. Previous studies have used only a straight-type HPHE configuration, while in this study, a combination of straight-type HPHEs and U-shape HPHEs were used. The use of the U-shape HPHE in this study was found to create an energy consumption saving in the hospital of up to $608.45 \mathrm{~W}$ or $2190.42 \mathrm{~kJ} /$ hour. Applied to actual conditions where the value of Te, $\mathrm{i}$ is less than $45^{\circ} \mathrm{C}$, such as in Indonesia, which experiences daily ambient temperatures ranging from 28 to 32 ${ }^{\circ} \mathrm{C}$, the potential savings to be made are in the range $200-350 \mathrm{~W}$. The effectiveness of the Ushape HPHE increases as the number of U-shape HPHEs increases and the air inlet temperature in the evaporator increases, while it falls as the air velocity increases. The value for HPHE heat recovery rises as the number of U-shape HPHEs increases, the evaporator inlet air temperature increases, and the air inlet velocity increases. The highest effectiveness of the U-shape HPHE is $7.64 \%$ and the lowest HPHE effectiveness is $0.30 \%$. The highest HPHE heat recovery is 608.45 $\mathrm{W}$, and the lowest HPHE heat recovery is $117.21 \mathrm{~W}$. 


\section{ACKNOWLEDGEMENT}

The authors are grateful for the financial support from Kemenristek Dikti RI through the PDUPT Scheme 2019 with contract number NKB-1651/UN2.R3.1/HKP.05.00/2019.

\section{REFERENCES}

Abtahi, H., Jayanth, M., Khattar, M.K., 1988. Theoretical Analysis of the Performance Characteristics of Dehumidification Heat Pipe Heat Exchangers in Air-conditioning Systems. In: American Society of Mechanical Engineers, Heat Transfer Division, (publication) HTD, ASME Proceedings of the 1988 National Heat Transfer Conference, July, 24-27

ASHRAE Standard, 1981. Thermal Environmental Conditions for Human Occupancy. American Society of Heating Refrigerating and Air Conditioning Engineers, Atlanta, Georgia, USA, pp. 55-81

Bearg, D., 1992. Indoor Air Quality and Humidity Control. Air Conditioning, Heating and Refrigeration News

El-Baky, M.A.A., Mohamed, M.M., 2007. Heat Pipe Heat Exchanger for Heat Recovery in Air Conditioning. Applied Thermal Engineering, Volume 27(4), pp. 795-801

Elfani, M., 2011. The Impact of Renewable Energy on Employment in Indonesia. International Journal of Technology, Volume 1, pp. 47-55

Firouzfar, E., Soltanieh, M., Noie, S.H., Saidi, M.H., 2011. Application of Heat Pipe Heat Exchangers in Heating, Ventilation and Air Conditioning (HVAC) Systems. Scientific Research and Essays, Volume 6, pp. 1900-1908

Jouhara, H., 2009. Economic Assessment of the Benefits of Wraparound Heat Pipes in Ventilation Processes for Hot and Humid Climates. International Journal of Low-Carbon Technologies, Volume 4(1), pp. 52-60

Jouhara, H., Merchant, H., 2012. Experimental Investigation of a Thermosyphon Based Heat Exchanger used in Energy Efficient Air Handling Units. Energy, Volume 39(1), 82-89

Jouhara, H., Meskimmon, R., 2018. An Investigation into the Use of Water as a Working Fluid in Wraparound Loop Heat Pipe Heat Exchanger for Applications in Energy Efficient HVAC systems. Energy, Volume 156, pp. 597-605

Hakim, I.I., Putra, N., Marda, A.P., Alvaro, M.A., Winarta, A., 2018. Experimental Study on Utilization of Heat Pipe Heat Exchanger for Improving Efficiency of Clean Room Air System in Hospitals. In: E3S Web of Conferences, EDP Sciences

Hassan, M.A.M., 2012. Investigation of Performance of Heat Pipe as Heat Exchanger using Alternative Refrigerants. Journal of Energy Engineering, Volume 139(1), pp. 18-24

Leung, M., Chan, A.H.S., 2006. Control and Management of Hospital Indoor Air Quality. Medical science Monitor, Volume 12(3), pp. SR17-SR23

McFarland, J.K., Jeter, S.M., Abdel-Khalik, S.I., 1996. Effect of a Heat Pipe on Dehumidification of a Controlled Air Space. In: American Society of Heating, Refrigerating and AirConditioning Engineers, Atlanta, Geprgia, USA, 17-21 Feb 1996

Muhammaddiyah, S., Winarta, A., Putra, N., 2018. Experimental Study of Multi-fin Heat Pipe Heat Exchanger for Energy Efficiency in Operating Room Air Systems. International Journal of Technology, Volume 9(2), pp. 422-429

Putra, N., Anggoro, T., Winarta, A., 2017. Experimental Study of Heat Pipe Heat Exchanger in Hospital HVAC System for Energy Conservation. International Journal on Advanced Science, Engineering and Information Technology, Volume 7(3), pp. 871-877

Shabgard, H., Allen, M.J., Sharifi, N., Benn, S., Faghri, A., Bergman, T.L., 2015. Heat Pipe Heat Exchangers and Heat Sinks: Opportunities, Challenges, Applications, Analysis, and State of the Art. International Journal of Heat and Mass Transfer, Volume 89, pp. 138-58 
Srimuang, W., Amatachaya, P., 2012. A Review of the Applications of Heat Pipe Heat Exchangers for Heat Recovery. Renewable and Sustainable Energy Reviews, Volume 16(6), pp. 4303-4315

Ting, C-C., Lee, J-N., Chen, C-C., 2009. Heat Transfer Characterizations of Heat Pipe in Comparison with Copper Pipe. Journal of Heat Transfer, Volume 131, pp. 1-6

Vakiloroaya, V., Samali, B., Fakhar, A., Pishghadam, K., 2014. A Review of Different Strategies for HVAC Energy Saving. Energy Conversion and Management, Volume 77, pp. 738-754

Winarta, A., Putra, N., Koestoer, R.A., Pamitran, A.S., Hakim, I., 2019. Experimental Investigation of a Large Scale-oscillating Heat Pipe at Different Inclinations. International Journal of Technology, Volume 10(2), pp. 258-268

World Health Organization, 2014. Access to Modern Energy Services for Health Facilities in Resource-constrained Settings: A Review of Status, Significance, Challenges and Measurement 